\title{
BIOLUMINESCENT IMAGING: NEW OPPORTUNITIES
}

\author{
Osipova ZM11,2, Shcheglov AS ${ }^{1,2}$, Yampolsky IV ${ }^{1,2}$ \\ ${ }^{1}$ Biomolecular Chemistry Department, Shemyakin-Ovchinnikov Institute of Bioorganic Chemistry of the Russian Academy of Sciences, Moscow \\ 2Laboratory of Natural Compounds Chemistry, Pirogov Russian National Research Medical University, Moscow
}

Modern biomedical research technologies actively use bioimaging for studying cells, tissues and whole organisms. Multicolor bioimaging is applied when simultaneous observation of different events at the molecular and cellular level is needed. Bioluminescent imaging methods are the most sensitive, however, their use for multicolor labeling is complicated due to the insufficient number of available uciferin-luciferase pairs. Having a number of advantages compared to previously studied bioluminescent systems, the new bioluminescence systems of higher fungi and marine polychaete Odontosyllis could become a useful expansion of the bioimaging toolbox.

Keywords: bioluminescence, bioimaging, luciferin, luciferase

Funding: the study was funded by the Ministry of Science and Higher Education of the Russian Federation under the Federal Targeted Programme for Research and Development in Priority Areas of Development of the Russian Scientific and Technological Complex for 2014-2020, Agreement \#14.613.21.0062, project identifier RFMEFI61317X0062.

$\triangle$ Correspondence should be addressed: Alexander S. Shcheglov

Miklukho-Maklaya 16/10, Moscow, 117997; jukart@mail.ru

Received: 02.11.2018 Accepted: 19.11.2018

DOI: $10.24075 /$ brsmu.2018.063

\section{БИОЛЮМИНЕСЦЕНТНЫЙ ИМИДЖИНГ: НОВЫЕ ВОЗМОЖНОСТИ}

\author{
3. М. Осипова ${ }^{1,2}$, А. С. Щеглов ${ }^{1,2}$, И. В. Ямпольский \\ 'Отдел биомолекулярной химии, Институт биоорганической химии имени М. М. Шемякина и Ю. А. Овчинникова РАН, Москва \\ 2 Лаборатория химии природных соединений, Российский национальный исследовательский медицинский университет имени Н. И. Пирогова, Москва
}

\begin{abstract}
Современные биомедицинские исследования активно используют методы биоимиджинга клеток, тканей и целых организмов. Многоцветный биоимиджинг находит свое применение в случае необходимости одновременного наблюдения разных событий на молекулярном и клеточном уровнях. Наиболее чувствительными являются методы биолюминесцентного имиджинга, однако их использование для многоцветного мечения сдерживается недостаточным количеством доступных пар люцифераза-люциферин. Удачным расширением палитры инструментов молекулярного имиджинга могут стать новые биолюминесцентные системы высших грибов и морской полихеты Odontosyllis, обладающие рядом преимуществ по сравнению с ранее изученными системами.
\end{abstract}

Ключевые слова: биолюминесценция, биоимиджинг, люциферин, люцифераза

Финансирование: работа выполнена при финансовой поддержке Министерства высшего образования и науки РФ в рамках реализации федеральной целевой программы «Исследования и разработки по приоритетным направлениям развития научно-технологического комплекса России на 2014-2020 годы», Соглашение № 14.613.21.0062, идентификатор проекта RFMEFI61317X0062.

$\searrow$ Для корреспонденции: Александр Сергеевич Щеглов ул. Миклухо-Маклая, 16/10, г. Москва, 117997; jukart@mail.ru

Статья получена: 02.11.2018 Статья принята к печати: 19.11.2018

DOI: $10.24075 /$ vrgmu.2018.063

Bioimaging of tissues and whole organisms is an integral part of the current research routines aimed at studying molecular events in the context of the disease development investigations [1]. Fluorescent and bioluminescent proteins (luciferases) are a very popular vehicle in bioimaging. For the purposes of fluorescent bioimaging, there was developed a set of fluorescent proteins with various spectral properties, ranging from violet to far-red, photoactivated and photoconvertible, as well as derivative sensors [2]. Luciferases that can be used for bioimaging are significantly more scarce than fluorescent proteins, but the methods making use of bioluminescence deliver some of the most accurate results when applied to examine deep tissues.

Luciferase catalyzes luminescence through oxidation of luciferin, molecular substrate, which allows receiving the analytical signal without using an external source of radiation, an integral part of the routine with fluorescent proteins. Thus, bioluminescent imaging in vivo is virtually free from background noise and offers unequaled sensitivity [3]. However, luciferases as reporter proteins are not flawless. The activity of some of them is strongly dependent on the number of cofactors and can be inhibited by intracellular components or medicines [4]. Still, despite bioluminescent systems being less practical because of the need for at least two components to trigger light emission, the relevant examination methods continue to evolve and gain popularity rapidly.

\section{Tools for bioluminescent imaging}

Multicolor bioimaging allows simultaneous observation of different events at the molecular level (e.g., gene expression or protein-protein interactions), which translates into a smaller number of animals used in the context of an experiment. There is a number of strategies to follow; some of them are: joint 
use of luciferases of different organisms, mutant luciferases of one organism, use of "luciferase-fluorescent protein" hybrid constructs, etc. [5].

Some of the most popular luciferases used for bioimaging are those of Photinus pyralis (62 kDa) Fluc, a North American firefly, Pyrophorus plagiophthalamus (62 kDa) $\left(\lambda_{\max } \approx 540-615 \mathrm{~nm}\right)$, a click beetle, and Renilla reniformis Rluc (36 kDa) and Gaussia princeps Gluc (20 kDa) $\left(\lambda_{\max } \approx 480 \mathrm{HM}\right)$, both of which are marine creatures [6]. Luciferases of terricole organisms catalyze the $D$-luciferinoxygen reaction in the presence of ATP and $\mathrm{Mg}^{2+}$ ions; luciferases of marine organisms utilize coelenterazine as a sole substrate. NanoLuc (19 kDa) $\left(\lambda_{\max }=460 \mathrm{~nm}\right)$, an engineered luciferase derived from the small domain of Oplophorus gracilirostris luciferase, has been very popular since 2012, when it was developed [7]. NanoLuc makes use of a different substrate, furimazine, a synthetic analogue of coelenterazine.

Apart from the purely historical reasons, luciferases catalyzing $D$-luciferin are popular because of their applicability to imaging the processes involving ATP molecule [8]. Also, there is a wide range of structural analogues of $D$-luciferin available [3], including those emitting in the more red portion of the spectrum, like the recently developed AkaLumine-HCl $\left(\lambda_{\max }=677 \mathrm{~nm}\right)$ [9]. It is necessary to clarify here that shifting bioluminescence to the near IR range is important because the spectral window for in vivo examination of processes in deep tissues belongs there. In addition to the improved spectral characteristics, AkaLumine- $\mathrm{HCl}$ distributes through the cells better than $D$-luciferin and saturates firefly luciferase (Fluc) more effectively. Directed mutagenesis of Fluc produced Akaluc, an artificial luciferase, the synthetic substrate of which is more active than the natural one [10]. The developed AlaBLI system is almost 100-1000 times brighter than other available systems; it allows bioimaging of a single deep tissue cells of freely moving animals.

Technologically, a light filter and different bioluminescent systems used together allow analysis of signals from different processes; to this effect, the standard Promega DLR assay contains both $P$. pyralis and $R$. reniformis luciferase. Another option is to introduce several mutant proteins to a single bioluminescent system. DART, a recently developed examination method, is an example of the latter. The system makes use of green (PLG) and red (PLR1) firefly luciferase mutants together with $D$-luciferin and its benzothiophene analogue, respectively [11]. However, the techniques described above are not flawless: the former carries a risk of light signal inhibition by luciferases, the latter can produce cross-reactions of the related luciferases with similar substrates.

Development of the fully artificial luciferases that work with standard substrates (based on the genetic sequences of known proteins) is an interesting approach to remedying the flaws, one similar to the approach that produced the aforementioned AlaBLI system. An example of the product thereof is Aluc, a recent development that interacts with coelenterazine and analogues $\left(\lambda_{\max }=487-500 \mathrm{~nm}\right)$ [12]. Chemical modification of coelenterazine by conjugation with fluorescent dyes allowed shifting the Aluc reaction's emission maximum to an even longer wavelength region [13]. Preliminary calculations in the context of an effort guided by a similar approach revealed several orthogonal pairs "D-luciferin analogue-mutant Fluc luciferase"; their activity was further confirmed in vivo [14].

Absence of cofactors in the luminescence reaction simplifies analysis and makes marine luciferases usable in extracellular imaging, which makes them a convenient vehicle. NanoLuc, an engineered luciferase, is especially popular. Its miniature size simplifies development of the new "luciferasefluorescent protein" fusion proteins used to expand the imaging palette with the help of the BRET technique. BRET is based on the Förster Resonant Energy Transfer (FRET) from luciferase to a fluorescent protein, which results in a shift of the emission maximum. NanoLuc luciferase and applicable proteins produced a whole range of chimeric proteins that have the emission maximum shifted to up to $680 \mathrm{~nm}$ with the help of various fluorophores [15]. The recently developed Rluc8-iRFPs chimeric proteins that also work in the long-wavelength portion of the spectrum are a similar example [16].

\section{Expansion of the palette: new luminescent system}

Studying new, previously unresearched luminescent systems is another approach to expanding the bioluminescent palette that shows promise. Some of the recent discoveries here include luciferin from Fridericia heliota $\left(\lambda_{\max }=480 \mathrm{~nm}\right)$, an earthworm, and that from fungi $\left(\lambda_{\max }=530 \mathrm{~nm}\right)$ [3]. Researchers have already obtained a recombinant luciferase for the latter [17]. The cost price of fungal luciferin is several orders of magnitude lower than that of $D$-luciferin while its stability is much higher. The new fungal bioluminescent system allows for a simple modification of luciferin structure, thus enabling production of the functional analogues emitting light in the longer wavelength range [18]; this property makes it a quite promising tool for bioimaging, even considering the membrane localization of the fungal luciferase, which may somewhat complicate its practical use.

In 2018, researchers isolated luciferase of Odontosyllis undecimonta, a marine polychaete [19]. This protein does not luminesce with the known luciferins of marine organisms (coelenterazine, Cypridina luciferin), which makes it the first marine luciferase belonging to a fundamentally new type of bioluminescent systems (i.e. orthogonal to all previously studied) described in a long time. In vivo, the bioluminescence of Odontosyllis peaks at around $510 \mathrm{~nm}$. The reaction between Odontosyllis luciferin and luciferase requires no cofactors, which is also the case for other marine luminescent systems. As soon as the structure of Odontosyllis luciferin is deciphered and its synthesis method developed, this bioluminescent system will be actively used in bioimaging.

\section{CONCLUSIONS}

A huge variety of multicolor bioimaging techniques available allows choosing the one optimal for the particular task in the context of a specific medical research. The most sensitive are the bioluminescent imaging techniques, but in terms of multicolor labelling, their application is limited by the insufficient number of available luciferase-luciferin pairs. The recently discovered bioluminescent systems of higher fungi and Odontosyllis, a marine polychaete, which have several advantages over those that are currently popular, can extend the palette. 
1. Cevenini L, Camarda G, Michelini E, Siciliano G, Calabretta MM, Bona R, Kumar TS, Cara A, Branchini BR, Fidock DA, Roda A. Multicolor bioluminescence boosts malaria research: quantitative dual-color assay and single-cell imaging in Plasmodium falciparum parasites. Anal Chem. 2014; 15; 86 (17): 8814-21.

2. Chudakov DM, Matz MV, Lukyanov S, Lukyanov KA. Fluorescent proteins and their applications in imaging living cells and tissues. Physiol Rev. 2010 Jul; 90 (3): 1103-63.

3. Kaskova ZM, Tsarkova AS, Yampolsky IV. 1001 lights: luciferins, luciferases, their mechanisms of action and applications in chemical analysis, biology and medicine. Chem Soc Rev. 2016; 45 (21): 6048-77.

4. Nakajima Y, Ohmiya Y. Bioluminescence assays: multicolor luciferase assay, secreted luciferase assay and imaging luciferase assay. Expert Opin Drug Discov. 2010; 5 (9): 835-49.

5. Yao Z, Zhang BS, Prescher JA. Advances in bioluminescence imaging: new probes from old recipes. Curr Opin Chem Biol. 2018; 45: 148-56.

6. Shimomura O. Bioluminescence: chemical principles and methods. Singapore: World Scientific; 2012.

7. Hall MP, Unch J, Binkowski BF, Valley MP, Butler BL, Wood MG, Otto P, Zimmerman K, Vidugiris G, Machleidt T, Robers MB. Engineered luciferase reporter from a deep sea shrimp utilizing a novel imidazopyrazinone substrate. ACS Chem Biol. 2012; 7 (11): 1848-57.

8. Rajendran M, Dane E, Conley J, Tantama M. Imaging adenosine triphosphate (ATP). Biol Bull. 2016; 231 (1): 73-84.

9. Kuchimaru T, Iwano S, Kiyama M, Mitsumata S, Kadonosono T, Niwa H, Maki S, Kizaka-Kondoh S. A luciferin analogue generating near-infrared bioluminescence achieves highly sensitive deeptissue imaging. Nat Commun. 2016; 7: 11856.

10. Iwano S, Sugiyama M, Hama H, Watakabe A, Hasegawa N, Kuchimaru T, Tanaka KZ, Takahashi M, Ishida Y, Hata J, Shimozono S. Single-cell bioluminescence imaging of deep tissue in freely moving animals. Science. 2018; 359 (6378): 935-9.

11. Branchini BR, Southworth TL, Fontaine DM, Kohrt D, Florentine CM, Grossel MJ. A Firefly luciferase dual color bioluminescence reporter assay using two substrates to simultaneously monitor two gene expression events. Sci Rep. 2018; 8 (1): 5990.

12. Kim SB, Nishihara R, Citterio D, Suzuki K. Fabrication of a new lineage of artificial luciferases from natural luciferase pools. ACS Comb Sci. 2017; 19 (9): 594-9.

13. Nishihara R, Hoshino E, Kakudate Y, Kishigami S, Iwasawa N, Sasaki SI, Nakajima T, Sato M, Nishiyama S, Citterio D, Suzuki K. Azide-and dye-conjugated coelenterazine analogues for a multiplex molecular imaging platform. Bioconj Chem. 2018; 29 (6): 1922-31.

14. Rathbun CM, Porterfield WB, Jones KA, Sagoe MJ, Reyes MR, Hua CT, Prescher JA. Parallel screening for rapid identification of orthogonal bioluminescent tools. ACS Cent Sci. 2017; 3 (12): 1254-61.

15. Hiblot J, Yu Q, Sabbadini MD, Reymond L, Xue L, Schena A, Sallin O, Hill N, Griss R, Johnsson K. Luciferases with tunable emission wavelengths. Angew Chem. 2017; 129 (46): 14748-52.

16. Rumyantsev KA, Turoverov KK, Verkhusha W. Near-infrared bioluminescent proteins for two-color multimodal imaging. Sci Rep. 2016; (6): 36588.

17. Kotlobay A, Sarkisyan KS, Mokrushina Yu, Marcet-Houben M, Serebrovskaya EO, Markina NM, et al. A genetically encodable bioluminescent system from fungi. Proc Natl Acad Sci USA. 2018; in press.

18. Kaskova ZM, Dörr FA, Petushkov VN, Purtov KV, Tsarkova AS, Rodionova NS, et al. Mechanism and color modulation of fungal bioluminescence. Sci Adv. 2017; 3 (4): e1602847.

19. Schultz DT, Kotlobay AA, Ziganshin R, Bannikov A, Markina NM, Chepurnyh TV, et al. Luciferase of the Japanese syllid polychaete Odontosyllis umdecimdonta. Biochem Biophys Res Comm. 2018; (502): 318-23.

\section{Литература}

1. Cevenini L, Camarda G, Michelini E, Siciliano G, Calabretta MM, Bona R, Kumar TS, Cara A, Branchini BR, Fidock DA, Roda A Multicolor bioluminescence boosts malaria research: quantitative dual-color assay and single-cell imaging in Plasmodium falciparum parasites. Anal Chem. 2014; 15; 86 (17): 8814-21.

2. Chudakov DM, Matz MV, Lukyanov S, Lukyanov KA. Fluorescent proteins and their applications in imaging living cells and tissues. Physiol Rev. 2010 Jul; 90 (3): 1103-63.

3. Kaskova ZM, Tsarkova AS, Yampolsky IV. 1001 lights: luciferins, luciferases, their mechanisms of action and applications in chemical analysis, biology and medicine. Chem Soc Rev. 2016; 45 (21): 6048-77.

4. Nakajima $\mathrm{Y}$, Ohmiya $\mathrm{Y}$. Bioluminescence assays: multicolor luciferase assay, secreted luciferase assay and imaging luciferase assay. Expert Opin Drug Discov. 2010; 5 (9): 835-49.

5. Yao Z, Zhang BS, Prescher JA. Advances in bioluminescence imaging: new probes from old recipes. Curr Opin Chem Biol 2018; 45: 148-56.

6. Shimomura O. Bioluminescence: chemical principles and methods. Singapore: World Scientific; 2012

7. Hall MP, Unch J, Binkowski BF, Valley MP, Butler BL, Wood MG, Otto P, Zimmerman K, Vidugiris G, Machleidt T, Robers MB. Engineered luciferase reporter from a deep sea shrimp utilizing a novel imidazopyrazinone substrate. ACS Chem Biol. 2012; 7 (11): 1848-57.

8. Rajendran M, Dane E, Conley J, Tantama M. Imaging adenosine triphosphate (ATP). Biol Bull. 2016; 231 (1): 73-84.

9. Kuchimaru T, Iwano S, Kiyama M, Mitsumata S, Kadonosono T, Niwa H, Maki S, Kizaka-Kondoh S. A luciferin analogue generating near-infrared bioluminescence achieves highly sensitive deep-

tissue imaging. Nat Commun. 2016; 7: 11856

10. Iwano S, Sugiyama M, Hama H, Watakabe A, Hasegawa N, Kuchimaru T, Tanaka KZ, Takahashi M, Ishida Y, Hata J, Shimozono S. Single-cell bioluminescence imaging of deep tissue in freely moving animals. Science. 2018; 359 (6378): 935-9.

11. Branchini BR, Southworth TL, Fontaine DM, Kohrt D, Florentine CM, Grossel MJ. A Firefly luciferase dual color bioluminescence reporter assay using two substrates to simultaneously monitor two gene expression events. Sci Rep. 2018; 8 (1): 5990.

12. Kim SB, Nishihara $R$, Citterio D, Suzuki K. Fabrication of a new lineage of artificial luciferases from natural luciferase pools. ACS Comb Sci. 2017; 19 (9): 594-9.

13. Nishihara R, Hoshino E, Kakudate $Y$, Kishigami S, Iwasawa N, Sasaki SI, Nakajima T, Sato M, Nishiyama S, Citterio D, Suzuki K. Azide-and dye-conjugated coelenterazine analogues for a multiplex molecular imaging platform. Bioconj Chem. 2018; 29 (6): 1922-31.

14. Rathbun CM, Porterfield WB, Jones KA, Sagoe MJ, Reyes MR, Hua CT, Prescher JA. Parallel screening for rapid identification of orthogonal bioluminescent tools. ACS Cent Sci. 2017; 3 (12): 1254-61.

15. Hiblot J, Yu Q, Sabbadini MD, Reymond L, Xue L, Schena A, Sallin O, Hill N, Griss R, Johnsson K. Luciferases with tunable emission wavelengths. Angew Chem. 2017; 129 (46): 14748-52.

16. Rumyantsev KA, Turoverov KK, Verkhusha W. Near-infrared bioluminescent proteins for two-color multimodal imaging. Sci Rep. 2016; (6): 36588.

17. Kotlobay A, Sarkisyan KS, Mokrushina Yu, Marcet-Houben M, 
Serebrovskaya EO, Markina NM, et al. A genetically encodable bioluminescent system from fungi. Proc Natl Acad Sci USA. 2018; in press.

18. Kaskova ZM, Dörr FA, Petushkov VN, Purtov KV, Tsarkova AS, Rodionova NS, et al. Mechanism and color modulation of fungal bioluminescence. Sci Adv. 2017; 3 (4): e1602847.

19. Schultz DT, Kotlobay AA, Ziganshin R, Bannikov A, Markina NM, Chepurnyh TV, et al. Luciferase of the Japanese syllid polychaete Odontosyllis umdecimdonta. Biochem Biophys Res Comm. 2018; (502): 318-23. 